\title{
Production and Characterisation of Cork Pellets: An Alternative for Sustainable Energy Recovery
}

\author{
L.J.R. Nunes ${ }^{1,2}$, J.C.O. Matias ${ }^{1}$ and J.P.S. Catalão ${ }^{1,3,4}$ \\ ${ }^{1}$ University of Beira Interior \\ R. Fonte do Lameiro, 6200-001 Covilhã (Portugal) \\ Phone: +351275329 914, Fax: +351275329972 \\ e-mail: d1213@ubi.pt; matias@ubi.pt; catalao@ubi.pt \\ ${ }^{2}$ YGE - Yser Green Energy SA, Zona Industrial de Taboeira, 3800-055 Aveiro, Portugal \\ ${ }^{3}$ INESC-ID, R. Alves Redol, 9, 1000-029 Lisbon, Portugal \\ ${ }^{4}$ IST, University of Lisbon, Av. Rovisco Pais, 1, 1049-001 Lisbon, Portugal
}

\begin{abstract}
The cork industry presents itself as one of the most entrepreneurial in the Portuguese industrial sector, contributing significantly to the increase of exports. However, it is an industry in which the use of raw materials is maximised leaving a large volume of waste. The cork industry has tried to take advantage of these residues, mainly through direct energy recovery, despite the technical and safety difficulties presented by the use of such low density material, which complicates and hinders its transportation for industrial uses outside the area in which it is produced. The densification process opens new doors for such use and also for its storage, because it produces better results when compared with other more common products, such as wood sawdust or even forest and agricultural waste. Thus, cork pellets emerge as a safer and more easily transportable alternative for energy recovery from cork dust and other granulated types of cork waste, which offer the prospects for wider use. The results demonstrate that cork pellets have higher calorific value when compared with other biomass pellets; typically, approximately $19 \mathrm{MJ} / \mathrm{kg}$ with $2 \%$ volume of ashes, which is equivalent to that obtained from the combustion of pellets produced from combined forest and agricultural waste with a bulk density of $640 \mathrm{~kg} / \mathrm{m}^{3}$, which offers real advantages in terms of logistics.
\end{abstract}

\section{Key words}

Cork waste, Cork pellets, Sustainable energy recovery.

\section{Introduction}

The Portuguese governmental strategy has set ambitious targets for using biomass for power and heat generation, which has resulted in a potential need for large amounts of biomass in the country [1]. Given the limited availability of residual forest biomass associated with the increasing production of biomass pellets in Portugal [2], already one of the leading European producers [3], once this industry has used large quantities of raw materials from the forest [4], interest in alternative forms of biomass increases, especially the waste from some industrial utilisations of biomass, such as cotton, paper and cork.

Cork that can be used as feedstock to replace other nonrenewable materials, such as petroleum and its derivatives, which is now regarded as a luxury product and has applications ranging from textiles and footwear to nanotechnology [5].

Traditionally, the cork industry has found uses for several cork by-products, including thermal energy recovery from cork dust, for which there is many other viable applications. However, its low density and volatility, leads to some technical and safety difficulties in terms of its energy use and there have been many cases of serious accidents in cork factories due to explosions and fires [6].

In Portugal, there is great experience in the production of wood pellets, especially regarding the use of indigenous types of wood, such as several types of pine (Pinus pinaster and Pinus pinea), eucalyptus (Eucalyptus globulus) and poplar (Populus sp.) [7], among others but also regarding the use of products of lesser economic importance, such as wood scrub resulting from forest clearing, cistus (Cistus ladanifer), gorse (Ulex europaeus), broom (Sarothamus scoparius), fetus (Pteridium aquilium) and brushwood (Rubus ulmifolius) [8].

Thus, the aim of this study was to pelletise and characterise a product made from industrial cork waste, demonstrating the feasibility of obtaining a pellet with good physical and energetic characteristics, demonstrating the logistical advantages of this densification and offering the possibility of using this form of biomass in other locations outside the cork industry. 


\section{The production of pellets}

Pellet production represents the possibility of using different types of biomass waste, which includes cork waste, by transforming them into a product with more homogeneous and uniform characteristics. This allows its use in the boilers of domestic or services buildings, such as schools and hospitals, similar to what already happens with the waste forms used as raw material in pellet production burned in advanced industrial boilers [9].

The production of biomass pellets is a sequence of steps that includes: pre-processing, drying, grinding, pelletizing, cooling, screening and bagging and is described briefly in this work.

The need for milling during pre-processing depends on the condition of the raw material to be used, i.e., it is often desirable to homogenise and mix the materials before pelletising. The same concept is applied to drying. This step is of fundamental importance for final product quality, because a raw material in which moisture content exceeds $15 \%$ becomes very difficult to pelletise properly. The greater or lesser need for drying of the materials before pelletising is a key factor for the amount of energy expended in the production of biomass pellets. In the case of cork waste, drying is usually not required because its characteristic is to present very low moisture content (10$15 \%)$.

In the next step, a hammer mill equipped with a $3.2 \mathrm{~mm}$ sieve reduces the dried cork waste to a usable size. The pelletising process is based on the extrusion of cork waste, or any other type of biomass, through the holes of a matrix. Sometimes, if the moisture content is too low, it may be necessary to add some water or vegetable oil to facilitate the extrusion process. This production process phase represents the largest share of electricity consumption in biomass pellet production and the main source of maintenance costs (up to $15 \%$ of annual maintenance costs) [10].

Cooling might also not be strictly necessary and represents low cost. Pellets are usually cooled immediately after pelletising, which helps to stabilise their form. Cooling systems often have one of two basic configurations of operation: horizontal or vertical airflow, the latter being the most widely used, which consists of a stream of air forced into contact with the pellets entering the pipe in countercurrent direction.

Sifting is necessary to separate the residual fines of the finished pellets before bagging. The fines and other debris collected in the sieve are returned to the refiner and reintroduced to the pelletising process. If the fines content exceeds $3 \%$ of the total amount of sieved product, this indicates that a problem has occurred with the raw material (moisture content or dimension of the particles) or the pelletising process itself (matrix form, compressibility, process temperature), which would need to be corrected.

The final step of an industrial pellet production process is bagging the finished products; usually $15 \mathrm{~kg}$ bags for residential consumers, or 700-1000 kg bags for largescale users. The bagging system can be manual, semiautomatic or fully automatic, depending on the size of the plant and the quantities produced. Pellets can also be transported in bulk tankers, discharging pellets using a pneumatic conveyer system to a silo or hopper.

\section{Materials and methods 3.1. Industrial cork waste}

Samples of cork granules were purchased from different cork companies in the area of Santa Maria da Feira (northern Portugal), in order to be representative of the waste produced in each of the industrial units.

This study aimed to reproduce the conditions of an industrial environment, in order to simulate the production of cork pellets on a large scale and in accordance with the restrictions that might occur on an industrial production line. Thus, in addition to the characterisation of cork pellets, it also confirms the feasibility of using a conventional biomass pellet production line, which normally uses traditional raw materials, such as the sawdust of pine or other common woods.

Given the variation between the different types of waste produced by the cork industry, after samples were taken and laboratory tests and trials carried out, the waste was subsequently mixed, in order to create a product suitable for use on a large scale.

During tests, feedstock was introduced into the pelletising press and sufficient water added to raise the moisture content to a value capable of reducing the friction between the material and matrix.

Another function of the added water is to allow the correct operation of the pelletising press without surge and vibration. However, this amount of water should not be too high in order to avoid producing poor quality pellets, which might easily disintegrate during transport and charging operations [11].

The optimal moisture content for industrial cork waste at the time of pelletizing is $15 \%$, because it is necessary to lower the natural compressive strength of these materials [12] and counterbalance the evaporation induced by the high temperature inside the pelletizing press.

This evaporation occurs mainly for two main reasons:

- Cork has high resistance to friction due to its natural roughness [13].

- The low permeability of the cork due to the high content of suberin [14].

Because there is a great use for all cork by-products, the resulting wastes are also different in their characteristics. However, using an all-in type mixture creates a final product with homogeneous characteristics, ensures a consistent raw material and emphasises the feasibility of industrial production of cork waste pellets. 


\subsection{Preparation of material for pelletizing}

Both the waste collection and sampling methods were conducted according to the direction of the draft standard FprEN 14778, Solid biofuels - sampling [15].

The raw material needed to be pre-treated because the particle size of the obtained mixture was not homogeneous.

It is accepted that for pellet production the appropriate size of the particles of the raw material is $3.20 \mathrm{~mm}$ [10]. For cork pellet production Munch - Edelshtal PMR 420 press with a theoretical capacity of $1000 \mathrm{~kg} / \mathrm{h}$ was used, which processed about $5000 \mathrm{~kg}$ of mixture of each sample. Indeed an industrial scale production test was considered, processing $5000 \mathrm{~kg}$ of cork waste, of which several samples were taken for laboratory analysis. With these amounts it was possible to stabilise the production and to achieve the optimal temperature for pellet production, because cork pellets reach their maximum durability when the matrix works at a temperature of $90{ }^{\circ} \mathrm{C}$. Accordingly, the permanent production of this type of pellets successfully started in 2012, producing about 500,000 kg of cork pellets per year.

Given the low moisture content of cork waste, typically about $6-8 \%$, it was necessary to raise the moisture level of the raw material during pellet production up to $15 \%$, as this is the ideal moisture content for pressing. Material with higher moisture content does not aggregate properly and with lower moisture content, there is an increased risk of fire inside the press.

This temperature, as indicated, yielded a final product with moisture content lower than $6 \%$ after being cooled at room temperature for $12 \mathrm{~h}$ (Fig. 1). However, it was found that unlike wood pellets, the cooling time of cork pellets is much less due to the particular thermal conductivity properties of the cork [13].

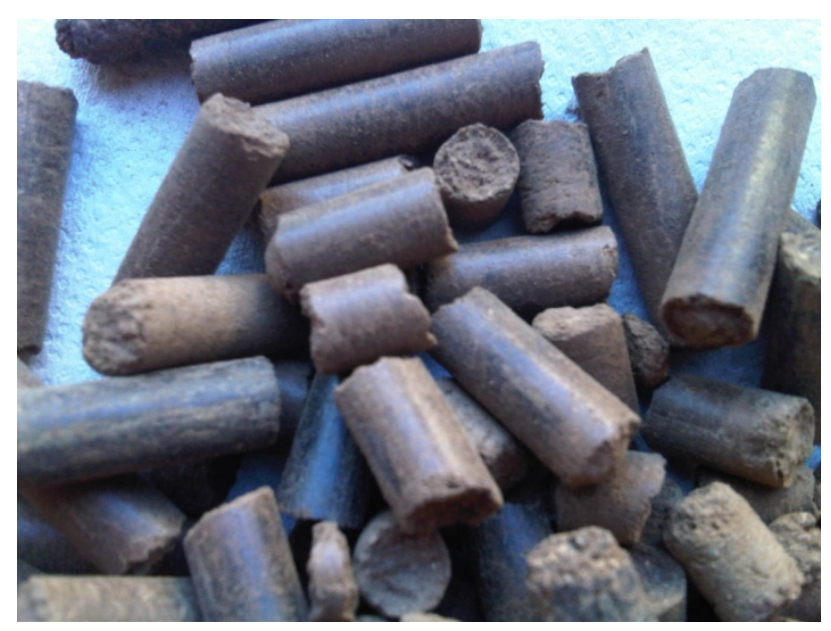

Fig. 1. Cork pellets.

\subsection{Characteristics of the pellets}

Table 1 summarizes the pellet quality parameters studied and the methods used. Each analysis was repeated three times so that the values reported represent mean values of the data obtained [16].

Table 1. Pellet quality parameters analyzed and methods.

\begin{tabular}{|c|c|c|}
\hline Parameter & Device/equipment & Method \\
\hline Bulk density & $\begin{array}{l}\text { Container with a } \\
\text { known volume }\end{array}$ & {$[17]$} \\
\hline Particle density & $\begin{array}{c}\text { Pycnometer } \\
\text { AccuPyc 1330, } \\
\text { Micromeritics } \\
\text { Instrument Corp. }\end{array}$ & [18] \\
\hline Durability & $\begin{array}{l}\text { Holmen Ligno } \\
\text { Tester }\end{array}$ & [19] \\
\hline Hardness & Kahl Tester & {$[20,21]$} \\
\hline L/D Ratio & Digital caliper & \\
\hline \multicolumn{3}{|l|}{ Proximate analysis } \\
\hline Moisture content & $\begin{array}{c}\text { Laboratory stove JP } \\
\text { SELECTA }\end{array}$ & {$[22]$} \\
\hline Ash content & $\begin{array}{c}\text { Laboratory oven } \\
\text { BOREL }\end{array}$ & [23] \\
\hline Volatile content & & [24] \\
\hline Ultimate analysis & $\begin{array}{c}\text { FISONS CARLO } \\
\text { ERBA EA } 1108 \\
\text { CHNSO detector [43 }\end{array}$ & [25] \\
\hline Heating value & $\begin{array}{l}\text { Bomb calorimeter } \\
(\text { Parr 6100) }\end{array}$ & [26] \\
\hline $\begin{array}{l}\text { Ash analysis by X- } \\
\text { ray fluorescence }\end{array}$ & $\begin{array}{c}\text { X-ray generator of } 4 \\
\text { kW power, model } \\
\text { PHILIPS Magix Pro } \\
(\text { PW-2440) }\end{array}$ & \\
\hline
\end{tabular}

Table 2 summarizes the physical and chemical characteristics of the pellets used in this study, which were obtained by means of the test procedures listed in Table 1.

Table 2. Characteristics of the pellets used in this study [16].

\begin{tabular}{|c|c|c|}
\hline Parameter & Cork Pellets & Units \\
\hline Bulk density & 640 & $\mathrm{Kg} / \mathrm{m} 3$ \\
\hline Particle density & 1204 & $\mathrm{Kg} / \mathrm{m} 3$ \\
\hline Durability & 97.74 & $\%$ \\
\hline Hardeness & 21.83 & $\mathrm{Kg}$ \\
\hline L/D ratio & 3.20 & \\
\hline \multicolumn{3}{|c|}{ Proximate abalysis } \\
\hline Volatiles & 79.3 & $\mathrm{Wt} \%$, as received \\
\hline Fixed carbon & 10.8 & $\mathrm{Wt} \%$, as received \\
\hline Moisture & 7.9 & $\mathrm{Wt} \%$, as received \\
\hline Ash & 2.0 & $\mathrm{Wt} \%$, as received \\
\hline \multicolumn{3}{|c|}{ Ultimate analysis } \\
\hline Carbon & 55.9 & $\mathrm{Wt} \%$, dry ash free \\
\hline Hydrogen & 5.6 & $\mathrm{Wt} \%$, dry ash free \\
\hline Nitrogen & 0.4 & $\mathrm{Wt} \%$, dry ash free \\
\hline Sulfur & 0.12 & $\mathrm{Wt} \%$, dry ash free \\
\hline Oxygen & 37.9 & $\mathrm{Wt} \%$, dry ash free \\
\hline \multicolumn{3}{|c|}{ Ash abalysis } \\
\hline $\mathrm{Na2O}$ & 3.3 & $\mathrm{Wt} \%$, dry basis \\
\hline MgO & 4.6 & $\mathrm{Wt} \%$, dry basis \\
\hline $\mathrm{Al2O3}$ & 2.3 & $\mathrm{Wt} \%$, dry basis \\
\hline $\mathrm{SiO2}$ & 7.4 & $\mathrm{Wt} \%$, dry basis \\
\hline P2O5 & 2.3 & $\mathrm{Wt} \%$, dry basis \\
\hline SO3 & 3.7 & $\mathrm{Wt} \%$, dry basis \\
\hline $\mathbf{C l}$ & 6.9 & $\mathrm{Wt} \%$, dry basis \\
\hline K2O & 12.6 & $\mathrm{Wt} \%$, dry basis \\
\hline $\mathrm{CaO}$ & 54.7 & $\mathrm{Wt} \%$, dry basis \\
\hline MnO & 0.6 & $\mathrm{Wt} \%$, dry basis \\
\hline Fe2O3 & 0.9 & $\mathrm{Wt} \%$, dry basis \\
\hline $\mathrm{ZnO}$ & 0.1 & $\mathrm{Wt} \%$, dry basis \\
\hline SrO & 0.3 & $\mathrm{Wt} \%$, dry basis \\
\hline TiO2 & 0.2 & $\mathrm{Wt} \%$, dry basis \\
\hline Other oxides & 0.2 & $\mathrm{Wt} \%$, dry basis \\
\hline LHV & 19.1 & $(\mathrm{MJ} / \mathrm{kg})$ \\
\hline
\end{tabular}




\section{Results and discussion}

From the performed tests it was found that the waste has low moisture content with a mean of $9 \%$, which means that during the pelletising process, water must be added until a moisture content of $15 \%$ is attained, prior to enter the pressing chamber.

Due to the high temperature resulting from friction between the raw material [27], the rollers and the matrix, which ideally reaches $94^{\circ} \mathrm{C}$, this moisture is released, leaving the pelleted cork with a final moisture of less than $8 \%$.

It appears that the moisture of the finished product is always less than that of the raw material.

This is because the production process occurs at higher temperatures than is usual for pellet production with other raw materials but also because of the properties of the cork itself, which has very small moisture content inside its particles [28].

The results obtained show an increase of Heating Value (HV) when compared with the original raw material, except cork dust (particle size below $0.05 \mathrm{~mm}$ and a density lower than $60 \mathrm{~kg} / \mathrm{m}^{3}$ ) and always higher when compared with the $\mathrm{HV}$ of the mixture obtained from the set of residues.

Cork pellets have an HV superior to the mean HV of other pellets produced from conventional types of wood $[29,30]$.

The percentage of ash is $2 \%$ and these values are very similar to those obtained by other researchers for other types of waste pellet, such as agricultural waste, cork pellets have a lower percentage of ash (e.g., 5.27\% for rye straw, $7.02 \%$ for wheat straw and $20.3 \%$ for rice husk) [31].

It is known that the density increases as the particle size decreases because the voids among the particles are smaller [10].

In this case, as the pellets are the result of a raw material formed by particles with different diameters (all-in type), this allows densities higher than $640 \mathrm{~kg} / \mathrm{m}^{3}$, i.e., more or less the same of conventional wood pellets [32].

The value obtained for cork pellet durability $97.74 \%$, which is very close to the results obtained with pellets from forest and agricultural waste [33].

Due to the densification process, unlike the traditional direct combustion of this waste of industrial origin, it is possible to obtain an alternative product with advantages over its prior use, which presents an array of features that enhance its use as a biofuel, similar to that resulting from other forest waste.

The analysed properties might vary in accordance with changes in the type of waste used, although the variability of the value, as verified, will not be very significant.

\section{Conclusions}

This paper presented an experimental investigation to produce cork pellets from cork industrial waste. The cork pellets emerge as a safer and more easily transportable alternative for energy recovery.

The properties of pelletised cork waste showed that it is suitable for energy applications because of improvements in its homogeneity, moisture and physical characteristics that enable improved control over the combustion process. As a consequence of the high content of suberin present in the cork waste, there is no need to add binders or other additives for the production of pellets.

Thus, with a set of characteristics similar to that of forest waste, together with higher bulk density, cork pellets acquire a transportation capacity that was not possible for cork waste, because of its low density, which allows new visions for its use outside of the cork industry for energy recovery or raw materials production, either in traditional form (direct combustion) or using alternative technologies (gasification), or even cork torrefaction that will allow direct co-firing with coal.

\section{Acknowledgement}

The authors would like to acknowledge the company Thermowall SA, from Portugal, which allowed cork pelletizing tests. This work was supported by FEDER funds (European Union) through COMPETE and by Portuguese funds through FCT, under Projects FCOMP01-0124-FEDER-020282 (Ref. PTDC/EEAEEL/118519/2010) and PEst-OE/EEI/LA0021/2013. Also, the research leading to these results has received funding from the EU Seventh Framework Programme FP7/2007-2013 under grant agreement no. 309048.

\section{References}

[1] Kaltschmitt M, Weber M. Markets for solid biofuels within the EU-15. Biomass Bioenergy 2006;30:897-907.

[2] DGGE. Estrategia Nacional para a Energia. A criação de uma rede de Centrais de Biomassa dedicadas. Direcção Geral de Geologia e Energia 2006.

[3] Viana H, Cohen WB, Lopes D, Aranha J. Assessment of forest biomass for use as energy. GIS - based analysis of geographical availability and locations of wood-fired power plants in Portugal. Appl Energy 2010;87:2551-60.

[4] Monteiro E, Mantha V, Rouboa A. The feasibility of biomass pellets production in Portugal. Energy Sources, Part B: Econ, Planning, Policy 2012;8(1):28-34.

[5] Pilão R, Ramalho E, Pinho C. Overall characterization of cork dust explosion. J Hazard Mater 2006;133(1-3):183-95.

[6] Garcia-Agreda A, DiBenedetto A, Russo P, Salzano E, Sanchirico R. Dust/gás mixtures explosion regimes. Powder Technol 2011;205(1-3):81-6. 
[7] Telmo C, Lousada J. Heating values of wood pellets from different species. Biomass Bioenergy 2011;35(7):2634-9.

[8] Mustelier NL, Almeida MF, Cavalheiro J, Castro F. Evaluation of pellets produced with undergrowth to be used as biofuel. Waste Biomass Valorization 2012;3(3):285-94.

[9] Mani S, Sokhansanj S, Bi X, Turhollow A. Economics of producing fuel pellets from biomass. Appl Eng Agric 2006;22(3):421-6.

[10] Wolf A, Vidlund A, Andersson E. Energy efficient pellet production in the forest industry - a study of obstacles and success factors. Biomass Bioenergy 2006;30:38-45.

[11] Mediavilla I, Fernández MJ, Esteban LS. Optimization of pelletisation and combustion in a boiler of $17.5 \mathrm{kWth}$ for vine shoots and industrial cork residue. Fuel Process Technol 2009;90:621-8.

[12] Pereira H. Mechanical properties - Cork: biology, production and uses. Elsevier; 2007. p. 207-25.

[13] Pereira H. Surface, thermal and other properties Cork: biology, production and uses. Elsevier; 2007. p. 227-39.

[14] Pereira H. The chemical composition of cork, Cork: biology, production and uses. Elsevier; 2007. p. 5599.

[15] FprEN 14778. Solid biofuels - sampling.

[16] Garcia-Maraver A et al. Relationship between fuel quality and gaseous and particulate matter emissions in a domestic pellet-fired boiler. Fuel 2013.

[17] EN 15103. Solid biofuels. Determination of bulk density; 2009.

[18] CEN/TS 15150. Solid biofuels. Methods for the determination of particle density; 2005.

[19] EN 15210-1. Solid biofuels. Determination of mechanical durability of pellets and briquettes. Pellets; 2009.

[20] Miranda T, Arranz JI, Montero I, Román S, Rojas CV, Nogales S. Characterization and combustion of olive pomace and forest residue pellets. Fuel Process Technol 2012;103:91-6.
[21] Kaliyan N, Morey VR. Factors affecting strength and durability of densified biomass products. Biomass Bioenergy 2009; 33:337-59.

[22] EN 14774-1. Solid biofuels. Determination of moisture content. Oven dry method. Part 1: Total moisture. Reference method; 2007.

[23] EN 14775. Solid biofuels. Determination of ash content; 2009.

[24] EN 15148. Solid biofuels. Determination of the content of volatile matter; 2009.

[25] EN 15104. Solid biofuels. Determination of total content of carbon, hydrogen and nitrogen. Instrumental methods; 2011.

[26] EN 14918. Solid biofuels. Determination of calorific value; 2009

[27] Guo Q, Liu H, Chen X. 2 Dimensional finite stochastic breakup model of biomass particle breakup. Bioresour Technol 2013;129:12-7.

[28] Wu MR, Schott DL, Lodewijks G. Physical properties of solid biomass. Biomass Bioenergy 2011;35:2093-105.

[29] Guo W, Lim CJ, Bi X, Sokhansanj S, Melin S. Determination of effective thermal conductivity and specific heat capacity of wood pellets. Fuel 2013;103:347-55.

[30] Nhuchhen DR, Salam PA. Estimation of higher heating value of biomass from proximate analysis: a new approach. Fuel 2012;99:55-63.

[31] Viana H, Vega-Nieva DJ, Ortiz Torres L, Lousada J, Aranha J. Fuel characterization and biomass combustion properties of selected native woody shrub species from central Portugal and NW Spain. Fuel 2012;102:737-45.

[32] ENplus - Certification of wood pellets for heating purposes. AEBIOM; 2011.

[33] Gil MV, Oulego P, Casal MD, Pevida C, Pis JJ, Rubiera F. Mechanical durability and combustion characteristics of pellets from biomass blends. Bioresour Technol 2010;101(22):8859-67. 